\title{
Protecting the Right to Vote: Oversight of the Department of Justice's Preparations for the 2008 Election - Statement of Gilda R. Daniels before the Senate Judiciary Committee, September 9, 2008
}

Gilda R. Daniels

University of Baltimore School of Law, gdaniels@ubalt.edu

Follow this and additional works at: http://scholarworks.law.ubalt.edu/all_fac

Part of the Civil Rights and Discrimination Commons, and the Election Law Commons

\section{Recommended Citation}

Protecting the Right to Vote: Oversight of the Department of Justice's Preparations for the 2008 Election - Statement of Gilda R. Daniels before the Senate Judiciary Committee, September 9, 2008 (September 9, 2008)

This Congressional and Other Testimony is brought to you for free and open access by the Faculty Scholarship at ScholarWorks@University of Baltimore School of Law. It has been accepted for inclusion in All Faculty Scholarship by an authorized administrator of ScholarWorks@University of Baltimore School of Law. For more information, please contact snolan@ubalt.edu. 
$\mathbf{u b}$

knowledge that works

School of Law

\title{
STATEMENT OF GILDA R. DANIELS
}

\author{
Before The Senate Judiciary Committee
}

Protecting the Right to Vote: Oversight of the Department of Justice's

Preparations for the 2008 General Election

PRESENTED ON SEPTEMBER 9, 2008

Gilda R. Daniels

Assistant Professor

(410) 837-4607

gdaniels@ubalt.edu 


\title{
Professor Gilda R. Daniels Senate Judiciary Committee Hearing Protecting the Right to Vote: Oversight of the Department of Justice's Preparations for the 2008 General Election September 9, 2008
}

\begin{abstract}
Chairman Leahy, Presiding Chair Senator Cardin and other distinguished members of the United States Senate Judiciary Committee, it is an honor to appear before you this afternoon to discuss ways that the Department of Justice can better prepare for the 2008 Presidential Election.

I have more than a decade of voting rights experience and served as a Deputy Chief under both the Clinton and Bush administrations. I was a Deputy Chief in 2000, when the country was crippled with hanging chads, dimpled ballots and faulty voting machines and worked within the Voting Section to address the myriad of issues that arose during that election. I served in the Department of Justice (DOJ), Civil Rights Division, Voting Section as a staff attorney from 1995 to 1998 and a Deputy Chief in that section for six years from 2000 to 2006. I also served as a staff attorney in the Voting Rights Project of the Lawyers' Committee for Civil Rights Under Law for two years. Currently, I am an Assistant Professor at the University of Baltimore, School of Law, where I teach Election Law among other topics.
\end{abstract}

\section{DOJ Presidential Election Experience}

In 2000, we witnessed faulty voting machines with hanging chads and dimpled ballots. We also experienced error-filled purges and voter intimidation in minority neighborhoods. Since the 2000 Presidential election the voting rights vocabulary has expanded to include terms such as, "voting irregularities" and "election protection" and created a new debate regarding voter access versus voter integrity. Despite the debates and new legislation in the form of the Help America Vote Act (HAVA), ${ }^{1}$ and the continued enforcement of other voting statutes such as the Voting Rights Act $^{2}$ and the National Voter Registration Act, (NVRA), problems persist in the operation of our participatory democracy.

\footnotetext{
${ }^{1}$ The Help America Vote Act of 2002 has the stated purpose of with the stated purpose of "establish[ing] a program to provide funds to States to replace punch card voting systems, to establish the Election Assistance Commission (EAC) to assist in the administration of federal elections and to otherwise provide assistance with the administration of certain federal election laws and programs, to establish minimum election administration standards for States and units of local government with responsibility for the administration of federal elections, and for other purposes." Help America Vote Act (HAVA), Pub. L. No. 107-252, 116 Stat. 1666 (2002); The HAVA is codified at 42 U.S.C. 15301 to 15545

${ }^{2}$ The Voting Rights Act, (VRA), which has been heralded as the most effective piece of Congressional legislation in our nation's history, outlawed practices such as literacy tests, empowered federal registrars to register citizens to vote, and gave the Attorney General the power to bring widespread litigation instead of the piecemeal approach of the past. As a result,
} 
Although outdated voting machines were not the primary problem in 2004, the use of electronic voting machines birthed new concerns about accuracy and reliability, along with questions regarding poll workers' ability to master the technology. This election enjoyed its share of election administration problems such as the misuse of provisional ballots, ${ }^{3}$ overzealous poll watchers, extremely long lines, deceptive voter practices, and ill-advised voter purges. In light of the problems and issues with the last two Presidential elections, it is vitally important that the Department use the full breadth of its statutory authority to act proactively to ensure that our democratic process provides every eligible citizen the opportunity to access the ballot and ensure that the ballot will be counted. In order to protect the fundamental right to vote, the government must act prior to Election Day. The Department should initiate contact with both state election officials and organizations to engage in a significant exchange of information in a nonpartisan and proactive way.

\section{DOJ Policy and Election Preparation}

After the 2000 election and certainly by 2002, the Civil Rights Division, Voting Section shifted its focus from enforcing the voting rights of minorities under Section 2 of the Voting Rights Act (VRA), as evidenced in the lack of cases brought on behalf of African-Americans, to enforcement of Section 203 for language minorities, the protection of overseas and military voters under UOCAVA, HAVA compliance and voter integrity (fraud) issues. In fact, this administration brought the first case pursuant to Section 2 on behalf of white voters in Noxubee, MS. ${ }^{4}$ This lack of enforcement of the Voting Rights Act would indicate a well documented shift away from enforcement of statutes that require free and full ballot access to a new emphasis on restricting the ballot in the name of integrity. This must be corrected.

\section{A. Election Coverage}

Under Section 4 of the VRA, the Attorney General may send federal observers to any jurisdiction that is required to submit all of its voting changes for review under Section 5 of the VRA or where provided in a Consent Decree. The majority of the Voting Section's preparation relies upon its election coverage,

wide disparities between blacks and whites in voter registration narrowed considerably throughout the South and the number of African-American elected officials increased tremendously.

${ }^{3}$ The Help America Vote Act requires states to provide provisional ballots, which allow voters whom election administrators would otherwise deem ineligible for reasons ranging from a lack of required ID to a voters name not appearing on the list of registered voters, to cast ballots despite lacking the proper identification or, in some states, attempting to vote in the wrong precinct.

${ }^{4}$ In 2005, the DOJ filed suit against the Noxubee County Democratic Executive Committee, Noxubee County Election Commission and Ike Brown, Chair of the Democratic Executive Committee in Noxubee, MS. See, United States v. Ike Brown, et.al., 494 F.Supp.2d 440 (S.D.Miss. 2007) 
which dispatches DOJ personnel under the direction of Voting Section attorneys to observe Election Day activities and report any irregularities to Voting Section managers and then work with the jurisdiction to correct those problems. The Voting Section, however, has limited staff and with the high rate of career attorney turnover, the level of expertise necessary in the area of election coverage will require an even higher level of training. Although the Voting Section dispatched more personnel to observe elections and upgraded its tracking of Election Day complaints, some of the "election coverage" merely consisted of an attorney with a cell phone in the US Attorneys' office. In order to have a meaningful presence ${ }^{5}$ that will dissuade attempts to disenfranchise eligible citizens, the Department should initiate contact with both state election officials and organizations to engage in a significant exchange of information in a nonpartisan and proactive way.

Because of the limited number of senior well trained staff, the Voting Section should provide a separate toll free number to the various Election Protection programs, in order for them to relay vital information of voting irregularities or voting rights statute violations to the Voting Section. Additionally, in preparing for election coverage, the Section should use its pre-election calls to insure that jurisdictions are prepared. It should also release the list of jurisdictions where it will provide election observers at least one week prior to Election Day. It should also limit the recent practice of utilizing the US Attorneys' offices and the $\mathrm{FBI}$, which are primarily trained in identifying voter fraud.

\section{B. Election-Related Investigations}

After the 2004 election, the Voting Section launched a few election related investigations which varied in intensity from phone calls to several visits. There were purge issues in Georgia; students with id problems in South Carolina, Illinois and Georgia; intimidation issues in South Carolina and Pennsylvania; claims of disproportionate voting resources in Florida and Ohio; and National Voter Registration Act issues in Delaware and Maryland. Most of these issues could have been addressed prior to Election Day with proper planning and guidance from DOJ. Many of the calls received or infractions observed on Election Day did not rise to a legally actionable level. Interestingly enough, the DOJ received far fewer calls than the estimated 110,000 that Election Protection groups received; an indication of the level of distrust and lack of confidence in the Department. After any election, however, no immediate remedy exists for the mistakenly purged voter or an uncounted provisional ballot, which further underscores the need for a proactive approach. Disenfranchisement techniques can create a pattern for a jurisdiction or a political party that should be addressed and thwarted well before Election Day.

\footnotetext{
${ }^{5} \mathrm{~A}$ benefit to having a more meaningful presence is the ability to collect data and identify potential witnesses for future election-related investigations.
} 


\section{New Problems: Changes in Election Administration Laws}

Since the 2004 Presidential election, the electoral landscape has changed. New voter identification and voter registration laws have made it more difficult for citizens to register and vote. Additionally, the use of ill-advised voter purges and deceptive practices continue to effect voters' access and ability to participate in the democratic process. DOJ could and should institutionalize preventative measures to address both new and recurring election related issues. ${ }^{6}$ Based upon my experience, I suggest that the DOJ employ the following proactive enforcement practices:

\section{A. $\quad$ Voter ID.}

As it pertains to voter id laws, the DOJ needs to monitor those states where the voter id laws have changed, since the 2004 election. Any change in rules that affect a voters' ability to cast a ballot, such as polling place changes, voter id, etc., can cause voter confusion. Therefore, it is essential that DOJ communicate with states to make sure that they are in compliance with voting statutes and that any changes of voting status or location is clearly communicated to the voter, well before the election.

Many states changed their voter id requirements to comply with the HAVA, which required that all first time voters who registered by mail without providing id verifying info must vote in-person and provide an acceptable form of id. ${ }^{7}$ In 2000 , only eleven states required all voters to show identification. In 2006, the number doubled to twenty-two states requiring all voters to present some form of id. Opponents have argued that voter id laws cause an undue burden on poor, minority, disabled, and elderly citizens and that the expense in obtaining even the "free" ids are cost prohibitive for many Americans. ${ }^{8}$ Proponents argue that more restrictive voter id laws are needed to prevent voter fraud.

The most restrictive requirement was passed in Indiana, which requires all voters to show a photo id before casting ballots. If the voter lacks a photo id, she must vote provisionally and subsequently return to the clerk's office and produce

\footnotetext{
${ }^{6}$ For further discussion on the cumulative effective of new millennium disenfranchising methods, see, Gilda R. Daniels, A Vote Delayed is a Vote Denied: A Preemptive Approach to Eliminating Election Administration Legislation that Disenfranchises Unwanted Voters, forthcoming in the University of Louisville Law Review, November 2008.

${ }^{7}$ HAVA requires the following identification: if voting in person, a drivers license or other photo id, a copy of a current utility bill, bank statement, government check, paycheck, or other government document that shows the name and address of the voter; or if voting by mail, voter must submit with the ballot a copy of a current and valid photo identification; or a copy of a current utility bill, bank statement, government check, paycheck, or other government document that shows the name and address of the voter.

${ }^{8}$ New voter id laws could adversely impact students, who may have a university id, but lack a photo id with an address within the state.
} 
a photo id or sign an indigency affidavit before the vote can be counted. The Supreme Court recently upheld this law. ${ }^{9}$ In 2005 , Georgia's passage of a similar voter id law set off what has been called a "firestorm" of activity in the media. Georgia is a state covered by Section 5 of the VRA, which requires specific jurisdictions to submit all voting changes- including but not limited to, polling place changes and redistricting- to either the United States Attorney General or the United States District Court for the District of Columbia for approval. $^{10}$ Georgia's submission to the Attorney General and the subsequent preclearance of the id legislation only fueled the flames. The proposed bill reduced the acceptable forms of voter identification from seventeen to five: a driver's license, a passport, a state or government issued ID, a military ID or a tribal ID. ${ }^{11}$

Although federal and state courts, as well as the United States Attorney General, have found these voter id laws constitutional, opponents continue to express their concern regarding the impact on those less likely to possess the requisite identification and their ability to cast a ballot. Thus, DOJ must correspond with states to determine whether a state ahs alerted its citizens to election administration changes or plan to include such information in any preelection mailings.

\section{B. Voter Registration.}

Regarding voter registration, the DOJ should contact those states where problems occurred in 2004, 2006 and during the Presidential primary season to make certain that jurisdictions are in compliance with voting rights statutes. DOJ should provide more oversight to ensure that jurisdictions are not rejecting

\footnotetext{
${ }^{9}$ Recently, in Crawford v. Marion County, the Supreme Court found that the Indiana legislature's purported rationale for passing the most restrictive voter id law in the country did not violate constitutional principles.

${ }^{10}$ See, 28 C.F.R. Part 51, Section 5 Regulations.

${ }^{11}$ The 17 acceptable forms of identification were as follows: valid Georgia driver's license; valid identification card issued by a branch, department, agency, or entity of the State of Georgia; another state, or the United States authorized by law to issue personal identification; valid United States passport; valid employee identification card containing a photograph of the elector and issued by any branch, department, agency or entity of the United States government, the State of Georgia, or any county, municipality, board, authority or other entity of Georgia; valid employee identification card contain a photograph of the elector issued by any employer of the elector in the ordinary course of business; valid student identification containing a photograph of the elector from any public or private college, university, or postgraduate technical or professional school located within the State of Georgia; valid Georgia license to carry a pistol or revolver; valid pilot's license; US military ID; birth certificate; Social security card; certified naturalization documentation; copy of court records showing adoption, name or sex change; utility bill; bank statement showing name and address of the elector; government check or payment with name and address of the elector or other government document showing name and address of the elector. Ga. Code Ann. §21-2-417.
} 
applications that provide sufficient information to determine the eligibility of an applicant. Further, it should encourage jurisdictions to do more follow-up with voters if the registration application does not provide enough information to determine eligibility.

The electoral process requires that states compile lists of eligible and legal voters. The NVRA requires States to maintain voter registration lists for federal elections. The NVRA considers applications received or postmarked at least 30 days before a federal election as timely. It also requires that election officials notify voters that their applications were accepted or rejected. The concern over voter registration is twofold: 1 ) the increase in state laws that restrict an organization's ability to register citizens (third-party registration) and 2) the increase in voter registration applications and election administrators' ability to process those applications prior to Election Day. Some states, e.g., Ohio, Florida, and Georgia, have made changes to voter registration procedures that make it more difficult for third parties, such as the League of Women Voters and the NAACP, to conduct voter registration drives. Litigation has already commenced in Ohio, Florida, Georgia and Pennsylvania. The inability of groups to perform voter registration could effectively diminish the number of eligible voters, who are able to register.

In 2004, the Department received a high number of calls from persons who stated that they registered to vote, yet their names were not on the voter rolls. In many instances, these persons were new registrants and their voter registration application was not processed. It is hoped that the remarkable increase in voters for the Presidential primaries alleviated some administrative processing problems. Therefore, state election officials should ensure that the counties are processing voter registration applications in a timely manner.

\section{C. $\quad$ Voter Purges.}

Concerning voter purges, DOJ should ensure that purges do not violate the safeguard provisions of the NVRA. At the same time, the DOJ should not ignore the primary purpose of the NVRA to establish procedures that will increase the number of eligible citizens who register to vote in elections for federal office.

The NVRA requires States to keep accurate and current voter registration lists, including purging those persons who have died or moved. Before removing persons or performing list maintenance procedures, the NVRA requires that list maintenance programs are uniform and non-discriminatory, comply with the Voting Rights Act, and can not occur 90 days before a federal election. States may only remove voters after complying with the NVRA's fail-safe provisions, which allow for removal of voters from registration lists if they have "been convicted of a disqualifying crime or adjudged mentally incapacitated," according 
to state law. ${ }^{12}$ The process of removing ineligible voters from state compiled registered voter lists is called voter purge. Although state governments have passed legislation that causes specific individuals, such as felons, to be ineligible voters, voter purge can also cause the removal or invalidation of eligible and legal voters from voter lists. Florida has been the center of numerous electoral debates due to the conflicts and controversies that surrounded the 2000 elections. Critics have called the voter purges in Florida during the 2000 election as "A wildly inaccurate voter purge lists that mistakenly identified 8,000 Floridians as felons thus ineligible to vote and that listed 2,300 felons, despite the fact that the state had restored their civil rights."13

There are various problems surrounding how voter lists are purged. Approximately, twenty-five percent of the states in an ACLU/Demos survey reported that they compile purge lists without reference to any legislative standards. About half of those surveyed purged their voter lists using only an individual's name and address, not a one hundred percent match involving full name and social security number. No state surveyed had codified any specific or minimum set of criteria for its officials to use in ensuring that an individual with a felony conviction is the same individual being purged from the voter rolls. Twothirds of the states surveyed do not require elections officials to notify voters when they purge them from the voter rolls, denying these voters an opportunity to contest erroneous purges.

Couple this with reports that DOJ threatened to sue ten states to purge voter rolls before the 2008 presidential election. ${ }^{14}$ Concerns have been raised that "the Justice Department's Voting Section is ignoring the primary purpose of the NVRA to 'establish procedures that will increase the number of eligible citizens who register to vote in elections for federal office." ${ }^{15}$ Instead of carrying out the primary function of the NVRA to increase voter registration, ${ }^{16}$ the DOJ's Voting Section is concentrating its NVRA enforcement priority on pressuring

\footnotetext{
${ }^{12}$ The NVRA also provides additional safeguards under which registered voters would be able to vote notwithstanding a change in address in certain circumstances. For example, voters who move within a district or a precinct will retain the right to vote even if they have not re-registered at their new address, which is at odds with the way some states administer provisional ballots, only counting those cast in the proper precinct.

${ }^{13}$ Verified Voting Foundation, Open Voter Purge List, http://www.verifiedvotingfoundation.org/article.php?id=2394 (June 12, 2004)

${ }^{14}$ See, New York Times Opinions/Editorial, What Congress Should Do, October 24, 2004Stephen Roosevelt, Bush Administration Orchestrating Massive Voter Purge Before 2008 Election, Veteransforcommonsense.org (July 17, 2007).

${ }^{15} \mathrm{Id}$.

${ }^{16}$ In a 2008 report for the Maryland Attorney General's Office, the Task Force on Voting Irregularities reported than in March 2008 only two persons were registered to vote at its social services agencies in March 2008. See, Report of the Attorney General's Task Force on Voting Irregularities, Maryland Office of the Attorney General, April 29, 2008, p. 12.
} 
states to conduct massive purges of their voter rolls. Although states need to maintain accurate voter rolls, the DOJ must remind states that they must comply with the safeguard requirements in the NVRA. Again, DOJ should not abandon the mandate of the NVRA to increase voter access to pursue its voter integrity initiatives.

\section{Voter Deception.}

On the topic of voter deception, the DOJ should use the full breadth of its authority found in 42 U.S.C. 1971(b) and 11(b) of the VRA to thwart deceptive voter practices. ${ }^{17}$

Today, we are seeing a resurgence of deceptive practices, particularly in African American and immigrant communities. Political parties and operatives engage in voter deception in an effort to confuse and thwart eligible voters from participating in the electoral process. These practices are a great cause of concern, but challenging these actions have been met with some resistance. The Justice Department has said, after the 2006 federal election that voter deception was beyond its authority; thus, prompting the initiation of new legislation.

In the $110^{\text {th }}$ Congress, Senators Obama and Schumer introduced the Deceptive Practices and Voter Intimidation Prevention Act of 2007, which would criminalize many of the deceptive voter practices and includes penalties of up to five years in prison for anyone who knowingly "conveys false information with the intent to keep others from voting." It increases from one to five years the penalty for anyone convicted of voter intimidation and requires the Attorney General to provide accurate election information when deception allegations are proven and to report to Congress on allegations of deceptions after each federal election. If passed this bill will fill a loophole for clearly deceptive practices and demonstrate the need for punishment and enforcement.

Prior to passage of this legislation, however, DOJ could certainly thwart deceptive practices that rise to the level of intimidation under its Voting Rights Act

${ }^{17} 42$ U.S.C. 1971 (b) reads as follows:

No person, whether acting under color of law or otherwise, shall intimidate, threaten, coerce, or attempt to intimidate, threaten, or coerce any other person for the purpose of interfering with the right of such other person to vote or to vote as he may choose, or of causing such other person to vote for, or not to vote for, any candidate for the office of President, Vice President, presidential elector, Member of the Senate, or Member of the House of Representatives, Delegates or Commissioners from the Territories or possessions, at any general, special, or primary election held solely or in part for the purpose of selecting or electing any such candidate.

See also, Section 11(b) of the Voting Rights Act. 
authority. ${ }^{18}$ DOJ has authority pursuant to 42 U.S.C. 1971 (b) to address voter intimidation and voter deception. The question remains whether it will choose to do so. It could publicize and utilize a toll free number for the sole pumose of chronicling deceptive practices across the nation. Once verified, in addition to sending a press release, the DOJ should immediately coordinate with state agencies and media outlets to correct any misleading information. It should also begin enforcement actions against perpetrators of deceptive practices.

\section{E. Poll Watchers.}

Regarding poll watchers, the DOJ should send a letter to states and organizations where this practice was problematic and require the state to fully comply with Sections 2 and 208 of the Voting Rights Act, which outlaws discriminatory voting practices or procedures.

Most states allow candidates to designate persons to "watch" the election process inside the polling place. These poll watchers, however, are not allowed to interfere with the voting process. In 2004, political candidates and parties dispatched thousands of attorneys and other individuals to "monitor" the administration of the election. We saw poll watchers launch an enormous number of strategic challenges to voters' eligibility, some based on race and language ability. Additionally, in some instances, at any given time, polls had more watchers than workers or actual voters.

In 2004, Republicans in Wisconsin attempted to challenge the registrations of 5,600 voters in Milwaukee but were turned down in a unanimous decision by the city's bipartisan election board. In Ohio, Republicans challenged 35,000 voters, after compiling their names through a caging scheme. ${ }^{19}$ The people on the list had either refused to sign letters delivered by the Republican Party or the letters had been returned as undelivered. Voters in Ohio won an injunction preventing challengers from remaining at voting-stations ${ }^{20}$

\footnotetext{
${ }^{18}$ In 1992, the DOJ filed and settled United States v. North Carolina Republican Party, C.A. No. 92-161CIV-5-F (E.D. N.C.), which involved the United States Senate election in North Carolina with African American Harvey Gantt versus incumbent Jesse Helms. In this action, the North Carolina Republican Party was accused with mailing postcards with misleading information as to voter eligibility, to registered voters prior to the November 1990 election. The postcards recipients were predominately African American.

${ }^{19}$ With one type of caging, a political party sends registered mail to addresses of registered voters. If the mail is returned as undeliverable - because, for example, the voter refuses to sign for it, the voter isn't present for delivery, or the voter is homeless - the party uses that fact to challenge the registration, arguing that because the voter could not be reached at the address, the registration is fraudulent. A political party challenges the validity of a voter's registration; for the voter's ballot to be counted, the voter must prove that their registration is valid.

${ }^{20}$ Spencer v. Blackwell, 347 F.Supp.2d 528 S.D.Ohio (2004).
} 
The Department should send a letter to states and organizations where this practice was problematic. Outreach, through the form of a letter, to organizations and state entities, should remind these groups and elected officials of the voters' rights and the process the poll watcher and poll worker should follow. Although the process for designating a poll watcher varies state to state these laws must comply with Section 2 of the Voting Rights Act, which outlaws discriminatory voting practices or procedures.

\section{F. Provisional Ballots.}

A consequence of excessive voter challenges was the use of provisional ballots. In some instances, due to misinformation or a lack of poll worker training, poll workers asked the challenged voter to cast a provisional ballot. In some states, if a voter cast a provisional ballot in the wrong polling place, pursuant to state rules, the provisional ballot was not counted. ${ }^{21}$ DOJ should make certain that jurisdictions are not administering provisional ballots with a discriminatory purpose or a discriminatory result.

\section{G. Disproportionate Allocation of Voting Machines}

Today, American citizens are registering to vote at exceptionally high rates. Minority and young voters are energized and eager to turnout and participate in what has certainly proven to be one of the most historic election cycles in our lifetimes. However, these efforts will prove futile if ultimately, these voters are unable to cast ballots that will count on Election Day. In many urban locations, voters are subjected to extremely long lines and faulty equipment. Although we had all hoped that HAVA would eliminate such occurrences, it has not. Curiously, the extremely long lines and undercounting of voting machines tend to occur in predominately African American areas. To address this problem DOJ should coordinate with HAVA's Election Assistance Commission (EAC) to determine if certain jurisdictions are "repeat offenders" and bring a Section 2 of the VRA claim. It could also coordinate with the EAC to establish "best practices"

\footnotetext{
${ }^{21}$ The administration of provisional ballots, however, has been called into question for the myriad of ways that election administrators determine whether to count the ballot. In 2004, the first year that HAVA required state's to provide provisional ballots, nearly 1.9 million of those ballots were cast and 1.2 million provisional ballots were counted, which left more than half a million people disenfranchised. See, Election Data Services, Election Day Survey, conducted for the U.S. Election Assistance Commission, at 6-5 (Sept. 27 2005). Moreover, poll worker confusion and unavailable ballots accounted for even more disparities. A People for the American Way report found:
}

There was widespread confusion over the proper use of provisional ballots, and widely different regulations from state to state-even from one polling place to the next-as to the use and ultimate recording of these ballots.

See, People for the American Way et al., Shattering the Myth: An Initial Snapshot of Voter Disenfranchisement in the 2004 Elections, at 8 (December 2004). 
for determining the number of voting machines per number of registered voters. Finally, Congress should use its Elections Clause Power and amend HAVA to mandate the number of voting machines per precinct and interpret HAVA to provide additional election administration reporting requirements. ${ }^{22}$

\section{Conclusion}

In my testimony, I have outlined some of the critical problem areas during the 2004 election cycle and proposed steps that the Justice Department should take to ensure that these problems are not repeated this November. However, it is essential that the Department act now.

The DOJ should immediately: 1) send letters to all states outlining federal voting rights statute requirements regarding voter purges, voter registration, UOCAVA, etc. with deadlines for action; 2) send letters and conduct calls to states with "observed" problems that could violate federal voting rights statues, e.g., lack of adherence to minority language requirements, information on particularly hostile areas/contests; 3 ) hold meetings with advocacy groups to "coordinate" election coverage; 4) provide jurisdictions and advocacy groups with a list detailing election coverage at least one week prior to the election; and 5) begin more extensive election coverage training of DOJ staff stressing "voter access" issues instead of "voter fraud.

On Election Day, DOJ should limit United States Attorney and FBI election coverage and "coordinate" communication with advocacy groups. DOJ should renew efforts to coordinate with civil rights and other organizations to discuss Election Day preparedness and learn how those groups plan to approach various voting irregularities and share how DOJ will address issues. For future elections, Congress should: 1) use its Elections Clause Power and amend HAVA to mandate the number of voting machines per precinct and 2) interpret HAVA to provide additional election administration reporting requirements. Finally, Congress should require DOJ to implement a timeline for election coverage proactive activity. Consequently, the best time to correct for potential disenfranchising methods is to establish a proactive plan NOW.

\footnotetext{
${ }^{22}$ For further discussion, see, Gilda R. Daniels, $A$ Vote Delayed is a Vote Denied: A Preemptive Approach to Eliminating Election Administration Legislation that Disenfranchises Unwanted Voters, forthcoming in the University of Louisville Law Review, November 2008.
} 